\title{
Medical Education: Curriculum Comparison between Brazil and Portugal
}

\author{
Antonio da Silva Menezes Junior, Iria Brzezinski \\ Pontifical Catholic University of Goias, Post-Graduation in Education Program Goiânia, Goiás, Brazil \\ Email: a.menezes.junior@uol.com.br
}

How to cite this paper: da Silva Menezes Junior, A., \& Brzezinski, I. (2018). Medical Education: Curriculum Comparison between Brazil and Portugal. Creative Education, 9, 1187-1195. https://doi.org/10.4236/ce.2018.98088

Received: March 27, 2018

Accepted: June 26, 2018

Published: June 29, 2018

Copyright (C) 2018 by authors and Scientific Research Publishing Inc. This work is licensed under the Creative Commons Attribution International License (CC BY 4.0).

http://creativecommons.org/licenses/by/4.0/

\section{cc) (i) Open Access}

\begin{abstract}
This research focuses on the educational policies and practices related to medical training. Historical materialism and dialectical approaches were used to conduct qualitative research using the comparison study of the two cases. The sample was intentional, with observations in two medical schools, one Institution A from Brazil and another Institution B from Portugal. The objective was to compare and analyze the curriculum policies and practices of organizations with respect to the educational policies of each country. The similarities between the courses were: 1) the teaching of student-centric curriculum and 2) the profile of the medical graduates. However, the largest differences were highlighted in the social integration proposed by Institution A, and the budget for research and for internationalization proposed by Institution B. In conclusion, it was observed that both institutions try to materialize the educational projects according to their current norms and seek to follow a reflective approach in order to achieve social transformation in contextual reality.
\end{abstract}

\section{Keywords}

Medical Education, Curriculum, Educational Policies, Qualitative Research

\section{Introduction}

This work aims to contribute to the scope of changes related to a world view, of man and woman, of education, of university, of training of trainers, of curriculum as a pedagogical practice, consistently motivated in education and health epistemology.

Therefore, it is believed in the indigence to achieve through coexistence and with the understanding of the two areas of professional practice, a level of "political awareness" (Freire, 1999) that allows to be teacher and critical doctor, in 
order to resize the praxis in favor to life.

The object of this research is the curricular policies of the course of medicine. The research, through the analysis of curriculum organization and its dynamics, proposes that the teaching methodology needs to be developed with emphasis on the questioning of social situations experienced by the students in different contexts and realities (Liao et al., 2014). The theoretical basis for this work is the communicative action theory of Jürgen Habermas.

The choice of Habermas' theory as a philosophical reference for this analysis is justified by the applicability of his concepts about the conception of the world, composed of subsystems, in which they operate using the instrumental reason, the strategic reason and the communicative reason (Habermas, 1986). The prevalence of instrumental reason and strategic action, in political and economic means, led to colonization and creation of a purpose-driven world. In it, training and medical practice, linked to the labor market, the person of the doctor, inscribed in the social and cultural context, and the laws of the state, break down consolidated truths and build new perspectives, which fit more appropriately to the panorama Current Social (Habermas, 1987a; 1987b; 1987c).

Concepts such as enlightenment, rationalization, rationality and modernity enable the temporal location, the chaining of historical facts, and gradually weave the meshes that provide support to the configuration of Habermasian Systemic world (Chernilo, 2002).

To Stotz (1993), in the health professions, doctors and nurses mainly act directly with human beings and get a feel for their actions to their needs, providing preventive, healthcare and searching for the cure of certain diseases. For this to happen, these professionals must interact with others using humanized scientific practices, in order to transform citizenship in the exercise of citizens inclusion.

It is therefore emphasized that a human being is not just a biological product. It is, above all, an agent in the health-disease process whose living conditions determined by the society. Freire (1998) clarifies that human beings transcend the biological because they are historical-social beings capable of reason and are, therefore, able to compare, value, choose and decide (Pezdek et al., 2017).

From the analysis of the reality and the context of future medical professionals, it is apparent that the importance of reflection on the communicative action is notorious. Action exercised among social actors, associated with the commitment to share health care in the country; the act is understood as a process of individual, social and cultural relations, in which the health professionals crisscross different trajectories.

\section{Objectives}

The objective of this paper is to conduct a comparative study of the historical, economic, cultural and educational contexts of Brazil and Portugal, particularly with respect to the Medical School of Institution A (Pontifical Catholic University of Goiás, 2011) and the Faculty of Health Sciences (2008) of Institution B, to 
examine the effectiveness of the training of doctors in the 21 st century. Further, it conducts this study in the light of the changes in the course of medicine caused by the curriculum guidelines (Brazil, 2001).

There are two specific objectives:

1) To establish a connection between the national curricular guidelines of the course of medicine in Brazil and the Agenda of Bologna, adopted by the medical course at the Institution B.

2) Analyze pedagogical practices using teaching method ologies based on questioning and problem solving, through interdisciplinary work, and through teacher and student feedback.

In view of the scope of these objectives, the main axes of the theoretical reference are the curricular guidelines for the medical courses in Brazil, arising from the implementation of the curricular reforms of higher education, based on the LDB 9.394/1996 and the academic qualifications of the Guidelines of the Bologna Convention/Bologna Agenda (1998).

\section{Methods}

The understanding of social reality is influenced by the theoretical references that correspond to the visions of the world that coexist in a society. The health-disease process, for example, as a manifestation of the social world, does not escape this process of interpretation.

In the context of medical training in this study, aiming at the Beginning Exercise of the profession, it will be highlighted for the category Work, since it interests the formation of the individual to the world of work. In this way, it is necessary to turn to Marx (1983), to understand two fundamental concepts: the work as "universal condition of the metabolism between man and nature" and the "use of labor force is the work itself" (Marx, 1983: p. 149).

The importance of the work, in this case, in which teachers and learners go together to the formation of the integral subject, as a citizen-doctor, may be expressed by the following question from Freitas (1995): "How do the learners appropriate the theoretical and methodological principles that allow the understanding of their pedagogical practice, of the social function of their work, of their historical project?" (Freitas, 1995: p. 44). Medical training and curricular policies of medical education were studied in Brazil and Portugal using analytical approach. At this point, the contextualization and characterization of these policies was sought.

The research focuses on the differences between the curricular policies adopted in the two contexts. Thus, it can be said that was used in this study, the comparative method. Therefore, it was necessary, in addition to the juxtaposition of these realities, to define and interpret facts and contexts to finally compare the two institutions.

Ehrensperger (2009) clarifies that the overlap recommends the establishment of similarities and differences from certain comparability criteria which may 
lead to the establishment of hypotheses for the realization of the next step-the analysis and affirmation of conclusions on the points compared.

The cases study allowed the deepening of knowledge of the curricular dynamics of each pedagogical project investigated, while the comparison allowed highlighting the approximation and the distance between these training projects for doctors, based on the theoretical assumptions adopted.

According to Schneider and Schmitt (1998), the method of comparison is correlated with the process of building knowledge, from the moment the cognitive activity is considered, and, above all, the abstraction. Comparative analysis enables the verification of regularities, the perception of shifts and transformations and the construction of models and typologies, identifying continuity and discontinuity, similarities and differences and, at the same time, explaining the determinations that can govern the social phenomena. In the case of this research, we chose to focus on the two cases, as mentioned, and in these we identify the approximations and distances.

In sociology, the discussion of the method of understanding for the construction of knowledge exists since the classical studies of the nineteenth century. Marx worked systematically through different historical cases, highlighting this method in his studies about the pre-capitalist economic formations. Otherwise, authors such as Comte, Durkheim and Weber used the same method to explain and generalize, considering that this analyze was correlated to the constitution of sociology as a specific field of knowledge (Schneider \& Schimitt, 1998).

The method of discussion allowed the examination of curricular policies for higher education in Brazil and Portugal. The establishment of convergences and divergences between them was pointed out by considering "a common platform of analysis", consisting of the worldwide agenda for globalized policies (Moraes, Pacheco, \& Evangelist, 2003).

As the study comes to the practices of curricular organization of each course studied, describing how these practices are realized in the actions of the managers (directors, pedagogic coordinators, administrative managers, among others), one can classify it as an institutional or organizational study.

This approach verifies how the practices experienced in universities respond and interpret the policies developed in each country. You must learn about the distance or the Educational proximity between the prescribed and the actual experienced at these institutions. It is, in a way, an evaluation process, because it was sought to demonstrate to what extent, and in what way, each institution implemented curricular policies in the process of organizing the curriculum (Ingrassia et al., 2018). The categories of analysis that gave support to the development of this work were: communication, emancipation, politics and power, dynamics and curriculum managements, praxis, social commitment.

In relation to the methodological data collection procedures, documentary analysis was carried out. To Ehrensperger (2009), a documentary analysis can be characterized as "a source of information that allows to gather, in relation to the object investigated, data obtained through non-interfering methods of research, 
as the documents already exist and many of them are produced by the agents themselves" (Ehrensperger, 2009: p. 73).

The selection of the courses investigated was given by means of an intentional sample, whose criteria were previously enumerated. In the proposed study, to analyze curricular practices in higher education, two universities were chosen to constitute the two cases to be studied: The medical, pharmaceutical, and biomedical sciences school course of Institution A in Brazil and Medical Course-Faculty of Health Sciences (FCS) - at Institution B (Interior of Portugal). The choice of the institutions mentioned was made because the researcher maintains professional ties with the Department of Brazilian medicine and academic links with the university in Portugal, and not because they are typical or statistically representative. These requirements do not apply in qualitative research and this research is "essentially analytical" (Ehrensperger, 2009: p. 76).

The pedagogical projects and the reformulations of both medical courses were analyzed. The analysis of the documents and the Observation in Portugal occurred from January 2011 to January 2012, be it in person (two visits at different times), or through exchange of information and data online, with the aim of restoring greater approximation between the organization and curriculum dynamics and analysis of recent documents. At the School of Health Sciences in Brazil, the observation was direct and continuous, throughout the period at Portugal, according to the schedule of the research in the European Union, it lasted three years and six months.

In completing, it is clearly observed that after the establishment of the method choice and the methodology used, the dialectical analysis of the results was obtained during the observation in the two chosen contexts. The analyzed categories can be strengthened, especially when the main removals or juxtapositions indicated are directed towards the difference to the labor market and the early social insertion or not of the graduate of the medical course, under the aegis of the national curricular guidelines in Brazil or the Bologna process in Portugal.

At first, the analytical approach was used to study medical training and curricular policies of medical education in Brazil and Portugal. At this point, the contextualization and characterization of these policies was sought.

Then, the interest was the specific context-course of medicine of Institution $\mathrm{A} / \mathrm{BR}$ and Institution B/PT - the focus of the work turned to the differences between the curricular policies adopted in the two contexts. To this end, it was necessary, in addition to the juxtaposition of these realities, to define and interpret the facts and contexts to finally compare the medical courses of the two institutions.

\section{Approximations and Distances}

The cases studied in historical, social, political, and economic contexts have very peculiar characteristics. There are, however, some similarities and differences between them and the most obvious ones are the approximations and distances, which can be thus stated: 
1) As regards the graduate of Institution $A / B R$, he or she is a general practitioner, has a critical vision and offers medical services in the labor market, searching for self-knowledge; The Institution B's graduate is also a general practitioner, with a critical view of the world, aware of the need to continually acquire international knowledge, skills, and attitudes.

2) The teaching methodology, developed by the two courses, complies with the normative standards of each context.

3) The hourly load and duration of the course, in numerical terms, are similar at the two institutions. The only difference is that at Institution B/PT the general practitioner is in the boarding school only in the last year (sixth year), while at Institution $\mathrm{A} / \mathrm{BR}$, the student goes to the boarding school starting fifth year.

4) The process of evaluating both courses is formative. In Institution B, accreditation is international, whether by the European system or by the United States of America based the Harvard Medical School, while at Institution A/BR, the evaluation is continuous, with integral activities, and accreditation is made by MEC/INEP and SINAES (National system for evaluation of higher education) through the ENADE (National examination of student performance).

5) The curricular organization follows similar models.

6) The curriculum management of the course at Institution B/PT is done by the Medical Education Office, responsible for curriculum, evaluation and curricular activities. The managers are a medical director and a pedagogical coordinator. The administration is collegiate because the Faculty of Health Sciences has a president and the decisions are shared with the administrative board, whereas in the course of Institution A/BR the management is the responsibility of the general Coordinator, and of the coordinators of each module. The academic-administrative decisions of relevance are taken in meetings with the collegiate of teachers.

7) The social exposure for the students in Institution B during the formative process, is done through covenants in hospitals that serve the public health network and there is a strong tendency to form a Doctor researcher, while the scholars of Institution A/BR are inserted in the public health system, at primary, secondary and tertiary (specialties) stages.

8) The internationalization of the Institution B medical course is done by an exchange program between European countries-ERASMUS-and by the development of integrated activities with the Harvard Medical School, while the Institution A/BR course has the practice of exchanges with Latin American, European (Portugal and Spain) and American universities.

\section{Discussion}

This study compares the national curricular guidelines of the course of medicine in Brazil and the guidelines from the Agenda of Bologna adopted in the medicine course at the Institution Bin Interior Portugal.

It was observed that in both cases curricular policies were determinant factors in the formation of the medical professional. In each case, a different variation of 
the traditional model of medical teaching was used. Both universities, in their pedagogical projects, proposed the formation of the general practitioner, based on a vision of the whole human being, guided by the biological, psychic and social aspects.

In the course of FCS Institution $\mathrm{B} / \mathrm{PT}$, the professional graduates must be prepared to meet the demands of the labor market, required by the historical and socio-cultural environment in which he or she lives. These demands encourage a young person to be competitive. The professional graduate has the competence not only to care as a family doctor, but also to exchange experiences, especially with regard to research. Remarkably, the title of the former student of the Institution B medical course, in accordance to Bologna process, is conferred by the master's degree in medicine.

In the medicine course at Institution $\mathrm{A} / \mathrm{BR}$, the professional is introduced early in the vocational cycle to the community work so that the primary functioning of the public health system becomes clear to him, besides the theoretical knowledge. The graduate of the course is also a general medical professional with a biopsychosocial vision critical capacity, and a strong social understanding. The extension programs make it possible for the medical professional to bring the knowledge from real-life experiences to the public health services for discussion, aimed at finding the alternative solutions in the academic sphere.

Another purpose of this study was to analyze the pedagogical practices initiated by the teaching methodology based on questioning and problem solving through teaching work and feedback of interdisciplinary students. It is noted that pedagogical practices are correlated with the profile of the student, as was foreseen by the national curricular guidelines of the course of medicine in Brazilas well as at the time of modifications that occurred in the pedagogical projects to meet the requests of the Bologna process in Portugal.

In the course of medicine at Institution $\mathrm{B} / \mathrm{PT}$, the curriculum is centered on the learner, with the conception of Praxis following the orientation of action-reflection-action and communicative action. This provides the formation of a critical physician who seeks autonomy and emancipation. To support this curriculum, the teaching methodology is objective-based learning, with the course divided into blocks and units. The student remains in basic training for two years, in vocational training for three years and, spends the last year at boarding school where he defends his master's dissertation. The research in the integrated master's degree is conducted in agreements and partnerships with international institutions.

In the course of medicine of Institution $\mathrm{A} / \mathrm{BR}$, the curriculum is based on the conceptions of critical theory concerning communicative action. It seeks to meet the national guidelines proposing emancipation and autonomy based on ethical-professional principles. During the course, the methodology of learning is based on problems and, as another guiding axis of the curriculum, the questioning, whose epistemological justification relates to the paradigm of community educational organization, participatory and democratic (Lee, Hahm, \& Lee, 
2018).

It is also found that both courses adopt curriculum oriented by national higher education policies to meet the demands of the labor market.

\section{Conclusion}

It is concluded that the greater distance between the two courses lies in the interest of each institution in catering to the labor market. While in Institution $B$ the professional is a master of medicine in six years and focuses on research, at Institution A the professional has a critical need to acquire knowledge, skills and attitudes to deal with the public health problems faced in everyday life.

\section{References}

Brazil./CNE/ECI. (2001). National Curriculum Guidelines for the Undergraduate Degree in Medicine. Higher Education Chamber. Resolution CNE/CES4/2001. Brasilia: Official Gazette of the Union, Section 1, 38.

Chernilo, D. (2002). The Theorization of Social Co-Ordinations in Differentiated Societies: The Theory of Generalized Symbolic Media in Parsons, Luhmann and Habermas. British Journal of Sociology, 53, 431-449. https://doi.org/10.1080/0007131022000000581

Ehrensperger, R. M. G. (2009). Policies and Practices Curricular in Higher Education. Brazil/Portugal Doctorate Thesis, Institute of Education and Psychology, University of Minho.

Faculty of Health Sciences (FCS) (2008). Medical Course Planning Project. Covilhã: University of the Beira Interior.

Freire, P. (1998). Pedagogy of Autonomy: Knowledge Needed for Educational Practice. Rio de Janeiro: Paz e Terra.

Freire, P. (1999). Pedagogy of the Oppressed (11 ${ }^{\text {th }}$ ed.). Rio de Janeiro: Paz e Terra.

Freitas, L. C. (1995). Critique of the Organization of Pedagogical Work and Teaching. Campinas: Papirus.

Habermas, J. (1986). Autonomy and Solidarity: Interviews with Jürgen Habermas. London: Ed. Verse.

Habermas, J. (1987a). Technique and Science as Ideology. Lisbon: Editions Seventy.

Habermas, J. (1987b). Théorie de l'agir communicationnel. Tome premier. Rationalité de lágir e rationalisation de La société. Traduit par Jean-Louis Schegel. Paris: Fayard.

Habermas, J. (1987c). Théorie de l'agir communicationnel. Tome second: Critique de la raison fonctionnaliste. Traduit de l"allemand par Jean-Louis Schegel. Paris: Fayard.

Ingrassia, P. L., Barozza, L. G., \& Franc, J. M. (2018). Prioritization in Medical School Simulation Curriculum Development Using Survey Tools and Desirability Function: A Pilot Experiment. Advances in Simulation, 3, 4. https://doi.org/10.1186/s41077-018-0061-x

Lee, H. Y., Hahm, M. I., \& Lee, S. G. (2018). Undergraduate Medical Students' Perceptions and Intentions Regarding Patient Safety during Clinical Clerkship. BMC Medical Education, 18, 66. https://doi.org/10.1186/s12909-018-1180-8

Liao, J. M., et al. (2014). Assessing Medical Students' Perceptions of Patient Safety: The Medical Student Safety Attitudes and Professionalism Survey. Academic Medicine, 89, 343-351. https://doi.org/10.1097/ACM.0000000000000124 
Martinez, M. M., Pacheco, J. A., \& Evangelist, O. (2003). Teacher Training, Educational and Curricular Perspectives. Porto, Portugal: Porto Editora.

Marx, K. (1983). Contribution to Criticism of the Political Economy(2nd ed.). Sao Paulo: Martins Fontes.

Pezdek, K., \& Doliński, W. (2017). Jürgen Habermas and the Dilemmas of Experience of Disability. Nursing Philosophy, 18, e12171. https://doi.org/10.1111/nup.12171

Pontifical Catholic University of Goiás (2011). Medical Course: Pedagogical Project. Goiania.

Schneider, S., \& Schimitt, C. J. (1998). The Use of the Method Compared in the Social Sciences. Sociology Books, 9, 48-97.

Stotz, N. (1993). Focus on Education and Health. In V. V. Valla and E.N. Stotz (Orgs.), Participation, Popular Education and Health: Theory and Practice ( $2^{\text {nd }}$ ed.). Rio de Janeiro: Relights. 